\title{
PENGETAHUAN IBU TENTANG DETEKSI DINI KANKER LEHER RAHIM DENGAN PAPSMEAR (Studi Kasus Di BPS Lilik Farida Surabaya)
}

\author{
Erlinda Aisa ${ }^{1}$, Sumiati ${ }^{2}$ \\ 1. Mahasiswa Program Studi D III Kebidanan Universitas PGRI Adi Buana Surabaya \\ 2. Tenaga Pengajar Program Stdi D III Kebidanan Universitas PGRI Adi Buana Surabaya
}

\begin{abstract}
ABSTRAK
Deteksi dini kanker leher rahim di Indonesia masih jarang ditemui, hal ini disebabkan oleh ketidaktahuan masyarakat tentang pentingnya deteksi dini kanker leher rahim, khususnya pada wanita usia reproduksi yang dapat dipengaruhi oleh beberapa faktor dan karakteristik ibu. Di Indonesia angka kematian ibu yang terjangkit kanker leher rahim masih sangat tinggi yang disebabkan oleh banyak hal salah satunya adalah bahan makanan yang banyak mengandung zat kimia. Tujuannya mengidentifikasi pengetahuan ibu tentang deteksi dini kanker leher rahim dengan papsmear berdasarkan usia, pendidikan, dan pekerjaan.

Desain penelitian menggunakan metode statistik deskriptif persentasi. Jumlah sampelnya ditetapkan sebanyak 30 responden akseptor KB pengambilan sampel dilakukan dengan menggunakan total sampling. Data diambil dengan menggunakan kuisioner, setelah data terkumpul diteliti kembali apakah data sudah cukup baik dan dapat disiapkan untuk proses berikutnya.

Hasil penelitian diperoleh 30 responden secara umum memiliki pengetahuan baik 11 responden (37\%), yang berpengetahuan cukup 13 responden (43\%), yang berpengetahuan kurang 6 responden (20\%). Berdasarkan usia responden yang berusia $20-30$ thn didapatkan pengetahuan baik 11 responden (40\%), pengetahuan cukup 11 responden (40\%) dan pengetahuan kurang 3 responden $(12 \%)$. Berdasarkan pendidikan didapatkan hasil : pengetahuan baik 4 responden $(37 \%)$ dengan pendidikan Perguruan Tinggi, pengetahuan cukup 7 responden (54\%) dengan pendidikan SLTA dan sebanyak 6 responden (100\%) dengan pendidikan SD - SLTP. Berdasarkan pekerjaan didapatkan hasil : responden pekerja swasta memiliki pengetahuan cukup 10 responden (59\%), PNS terbanyak pengetahuan cukup 2 responden (100\%) dan tidak bekerja terbanyak 7 responden (67\%) pengetahuan cukup. Adapun saran yang disampaikan, peneliti berharap dapat mengubah pola pikir masyarakat yang mengenyampingkan pemeriksaan papsmear dan tenaga kesehatan dapat meningkatkan upaya promotif menggalakkan penyuluhan khususnya untuk kesehatan reproduksi wanita diberbagai wilayah tidak hanya kota saja tetapi juga daerah yang sulit dijangkau.
\end{abstract}

Kata kunci : Pengetahuan ibu, deteksi kanker leher rahim, papsmear

\section{PENDAHULUAN}

\section{Latar Belakang}

Sebagai seorang wanita kita perlu menjaga kondisi tubuh mulai dari ujung rambut sampai kaki, tidak hanya bagian luar saja yang dirawat dan dijaga melainkan organ dalam pun juga harus diperhatikan, misalnya rahim banyak mengalami perubahan yang tidak menentu hal ini harus diwaspadai pada setiap orang, perlunya pemeriksaan papsmear ditujukan untuk menurunkan angka kematian akibat kanker leher rahim. Dengan papsmear kanker leher rahim bisa terdeteksi lebih awal dan dapat disembuhkan jika stadium awal. Saat ini banyak ditemui wanita datang berobat setelah timbul suatu gejala seperti keputihan yang banyak dan berbau menyengat ternyata setelah diperiksa ditemukan sudah stadium lanjut. Penting dalam papsmear adalah pemeriksaan vagina dengan spekulum untuk diambil sampel cairan porsionya dan diperiksakan ke laboratorium.

Total jumlah wanita yang didiagnosis kanker leher rahim di Amerika Serikat pada tahun 1999 adalah 12900 dengan kematian yang berkaitan dengan kanker sejumlah 4400, sedangkan wanita yang mengidap kanker leher rahim di seluruh dunia sekitar 471000, dengan angka kematian 215000. Di banyak negara berkembang, kanker leher rahim merupakan penyebab kematian paling umum di usia reproduksi.(Rasjidi, Imam.2009;99)

Diagnosis kanker leher rahim masih
sering terlambat 
penanganannyapun ternyata tidak memberi hasil yang baik. Terlambatnya diagnosis terjadi karena penderita sering datang terlambat ke dokter ataupun disebabkan gejala yang sulit terdeteksi oleh dokter menemukan penyakit tersebut pada tingkat dini.

Biasanya penderita datang ke dokter setelah terjadi gejala perdarahan per vaginam yang tidak semestinya atau terdapat keputihan yang berbau. Jika terjadi perdarahan per vagina atau terdapat keputihan, sering wanita tidak pergi ke dokter tetapi mengusahakan sendiri mengatasinya dengan minum jamu atau pergi ke dukun. Apabila dengan usaha tersebut gejala tidak teratasi atau mungkin menghebat, barulah mereka pergi ke dokter. Hal ini disebabkan karena kurangnya pengertian akan bahaya kanker, karena pendidikan yang kurang atau kurangnya penerangan mengenai kanker umumnya, kanker leher rahim khususnya. Tidak jarang pula mereka takut jika dokter menemukan kanker pada dirinya. Ketakutan yang tidak beralasan ini dikarenakan bahwa kanker tidak dapat diobati dan selalu dihubungkan dengan kematian.

Dilakukannya deteksi dini dengan papsmear untuk mengetahui ada tidaknya penyakit kanker leher rahim, jika seorang wanita terjangkit maka segera dilakukan pemeriksaan lebih lanjut dengan berbagai terapi jika stadium awal besar kemungkinan bisa disembuhkan namun jika stadium sudah lanjut bisa dilakukan kemoterapi, kalau di biarkan atau tidak terdeteksi saat ini maka akan berakhir dengan kematian.

Tujuan Umum dalam penelitian ini adalah: mengetahui pengetahuan ibu tentang deteksi dini kanker leher rahim dengan papsmear. Tujuan khususnya adalah : 1. Mengidentifikasi pengetahuan ibu tentang deteksi dini kanker leher Rahim dengan papsmear secara umum, 2. Mengidentifikasi pengetahuan ibu tentang deteksi dini kanker leher Rahim dengan papsmear berdasarkan usia, 3. Mengidentifikasi pengetahuan ibu tentang deteksi dini kanker leher Rahim dengan papsmear berdasarkan pendidikan, 4. Mengidentifikasi pengetahuan ibu tentang deteksi dini kanker leher Rahim dengan papsmear berdasarkan pekerjaan.

\section{Bahan dan Metode}

Rancangan penelitian yang dipilih adalah penelitian diskriptif, dimana peneliti berupaya menggambarkan pengetahuan tentang deteksi dini kanker leher Rahim dengan papsmear. Penelitian dilakukan di BPS Lilik Farida yang dilaksanakan pada bulan Juni 2012. Populasi dalam penelitian adalah semua Akseptor KB sebanyak 30 responden. Pengambilan sample dengan total sampling dan instrument penelitian menggunakan angket / kuisioner untuk mengukur pengetahuan ibu. Data yang dikumpulkan oleh peneliti berupa data karakteristik ibu ( umur, pendidikan, pekerjaan ) dan pengetahuan ibu tentang deteksi dini kanker leher rahim dengan papsmear. Setelah data terkumpul selanjutnya di analisis dengan statistik, diskriptif persentase.

\section{Hasil dan pembahasan}

Berdasarkan penelitian terhadap 30 responden didapatkan hasil sebagai berikut :

Tabel 1. Distribusi Frekuensi Responden Berdasarkan Pengetahuan lbu Tentang Deteksi Dini Dengan Papsmear Di BPS Lilik Farida Surabaya Pada Bulan Juni 2012

\begin{tabular}{|c|c|c|c|}
\hline No & Pengetahuan & $\mathrm{n}$ & $\%$ \\
\hline 1 & Baik & 11 & $37 \%$ \\
2 & Cukup & 13 & $43 \%$ \\
3 & Kurang & 6 & $20 \%$ \\
\hline & Jumlah & 30 & $100 \%$ \\
\hline
\end{tabular}

Berdasarkan tabel 1 dapat dijelaskan bahwa dari 30 responden yang berpengetahuan baik 11 responden $(37 \%)$, yang berpengetahuan cukup 13 responden (43\%), yang berpengetahuan kurang 6 responden (20\%).

Tabel 2. Tabulasi Silang Pengetahuan Ibu Tentang Deteksi Dini Dengan Papsmear Berdasarkan Usia Di BPS Lilik Farida Surabaya.

\begin{tabular}{|c|l|c|c|c|c|c|c|c|c|}
\hline \multirow{3}{*}{ No } & \multirow{3}{*}{$\begin{array}{l}\text { Penget } \\
\text { ahuan }\end{array}$} & \multicolumn{4}{|c|}{ Usia (tahun) } & \multicolumn{2}{|c|}{$\Sigma$} \\
\cline { 3 - 10 } & & $<20$ & $20-30$ & \multicolumn{2}{|c|}{$\Sigma$} \\
\cline { 3 - 10 } & $\mathrm{n}$ & $\%$ & $\mathrm{n}$ & $\%$ & $\mathrm{n}$ & $\%$ & $\mathrm{n}$ & $\%$ \\
\hline 1 & Baik & 0 & 0 & 11 & 40 & 0 & 0 & 11 & 100 \\
2 & Cukup & 0 & 0 & 11 & 40 & 2 & 15 & 13 & 100 \\
3 & Kurang & 0 & 0 & 3 & 12 & 3 & 50 & 6 & 100 \\
\hline
\end{tabular}

Dari tabel diatas dapat disimpulkan bahwa dari 30 responden, 20-30 tahun yang mempunyai pengetahuan baik dalam pemeriksaan papsmear 
terbanyak 11 responden (100\%), 20-30 tahun yang mempunyai pengetahuan cukup terbanyak 11 responden (85\%), dan > 40 tahun yang mempunyai pengetahuan kurang terbanyak 3 responden $(50 \%)$.

Tabel 3. Tabulasi Silang Pengetahuan lbu Tentang Deteksi Dini Dengan Papsmear Berdasarkan Pendidikan Di BPS Lilik Farida Surabaya

\begin{tabular}{|c|l|c|c|c|c|c|c|c|c|}
\hline \multirow{2}{*}{ No } & \multirow{2}{*}{$\begin{array}{l}\text { Penget } \\
\text { ahuan }\end{array}$} & \multicolumn{5}{|c|}{ Pendidikan } & \multicolumn{2}{|c|}{$\begin{array}{c}\text { SD- } \\
\text { ahu }\end{array}$} & \multicolumn{2}{|c|}{ SLTA } & \multicolumn{2}{|c|}{ PT } & \multicolumn{2}{|c|}{$\Sigma$} \\
\cline { 3 - 10 } & & $\mathrm{n}$ & $\%$ & $\mathrm{n}$ & $\%$ & $\mathrm{n}$ & $\%$ & $\mathrm{n}$ & $\%$ \\
\hline 1 & Baik & 4 & 37 & 3 & 27 & 4 & 37 & 11 & 100 \\
2 & Cukup & 6 & 46 & 7 & 54 & 0 & 0 & 13 & 100 \\
3 & Kurang & 6 & 100 & 0 & 0 & 0 & 0 & 6 & 100 \\
\hline
\end{tabular}

Dari tabel diatas dapat disimpulkan bahwa 30 responden yang berpendidikan SD-SLTP dan PT yang mempunyai pengetahuan baik terbanyak 4 responden (37\%), yang berpendidikan SLTA mempunyai pengetahuan cukup terbanyak 7 responden (54\%), yang berpendidikan SD-SLTP mempunyai pengetahuan kurang terbanyak 6 responden (100\%).

Tabel 4. Tabulasi Silang Pengetahuan lbu Tentang Deteksi Dini Dengan Papsmear Berdasarkan Pekerjaan Di BPS Lilik Farida Surabaya.

\begin{tabular}{|c|l|c|c|c|c|c|c|c|c|}
\hline \multirow{2}{*}{ No } & \multirow{2}{*}{$\begin{array}{c}\text { Penget } \\
\text { ahuan }\end{array}$} & \multicolumn{6}{|c|}{$\begin{array}{c}\text { Pengetahuan tentang } \\
\text { Papsmear }\end{array}$} & $\begin{array}{c}\text { Tidak } \\
\text { bekerja }\end{array}$ & \multicolumn{2}{|c|}{ Swasta } & \multicolumn{2}{c|}{ PNS } & \multicolumn{3}{c|}{$\Sigma$} \\
\cline { 3 - 10 } & & $\mathrm{n}$ & $\%$ & $\mathrm{n}$ & $\%$ & $\mathrm{n}$ & $\%$ & $\mathrm{n}$ & $\%$ \\
\hline 1 & Baik & 3 & 27 & 7 & 41 & 2 & 100 & 12 & 100 \\
2 & Cukup & 7 & 67 & 10 & 59 & 0 & 0 & 17 & 100 \\
3 & Kurang & 1 & 6 & 0 & 0 & 0 & 0 & 1 & 100 \\
\hline
\end{tabular}

Dari tabel diatas dapat disimpulkan bahwa dari 30 responden yang swasta mempunyai pengetahuan baik terbanyak 7 responden $(41 \%)$, yang swasta mempunyai pengetahuan cukup terbanyak 10 responden (59\%), yang tidak bekerja mempunyai pengetahuan kurang terbanyak 1 responden (6\%).

\section{PEMBAHASAN}

Setelah dianalaisa dan dijabarkan dalam bentuk tabel akan diuraikan tentang pembahasan hasil penelitian yang telah dilakukan dari data diatas sehingga dapat disimpulkan bahwa pengetahuan ibu tentang deteksi dini kanker leher rahim dengan papsmear dapat di pengaruhi oleh usia, pendidikan, dan pekerjaan.

\section{Pengetahuan Ibu Tentang Deteksi Dini Kanker Leher Rahim Dengan Papsmear Secara Umum}

Berdasarkan hasil penelitian pengetahuan tentang deteksi dini kanker leher rahim dengan papsmear sesuai dengan tabel 1 maka dapat diperoleh bahwa dari 30 responden yang berpengetahuan baik 11 responden (37\%), yang berpengetahuan cukup 13 responden $(43 \%)$, yang berpengetahuan kurang 6 responden $(20 \%)$.

\section{Pengetahuan Ibu Tentang Deteksi Dini Kanker Leher Rahim Dengan Papsmeaar Berdasarkan Usia}

Usia adalah umur individu yang terhitung mulai saat dilahirkan sampai saat berulang tahun. Semakin cukup umur tingkat kematangan dan kekuatan seseorang akan lebih matang dalam berpikir, bersosialisasi, dan beraktifitas dalam kehidupan sehari-hari. Dari kepercayaan masyarakat yang lebih dewasa akan lebih dipercaya dari pada orang yang belum cukup tinggi kedewasaannya. Hal ini sebagai akibat dari pengalaman dan kematangan jiwanya (Nursalam,2003)

Hal ini tidak sesuai dengan teori berdasarkan tabel 2 ditemukan bahwa dari 30 responden 20-30 tahun yang mempunyai pengetahuan baik dalam pemeriksaan papsmear terbanyak 11 responden (100\%), 20-30 tahun yang mempunyai pengetahuan cukup terbanyak 11 responden (85\%), dan > 40 tahun yang mempunyai pengetahuan kurang terbanyak 3 responden $(50 \%)$, hal ini dikarenakan pada usia 20-30 tahun adalah usia produktif sehingga pola pikir/ pengetahuan tentang papsmear masih sangat tinggi sedangkan pada usia $>40$ tahun beranggapan bahwa melakukan pemeriksaan itu tidak penting lagi kemungkinan besar dikarenakan usia mereka yang mendekati masa menopause serta enggan untuk diperiksa karena harus membuka anggota tubuh bagian bawah.

\section{Pengetahuan Ibu Tentang Deteksi Dini Kanker Leher Rahim Dengan Papsmeaar Berdasarkan Pendidikan}


Berdasarkan tabel 3 dapat dilihat bahwa dari 30 responden berpendidikan SD-SLTP dan PT yang mempunyai pengetahuan baik terbanyak 4 responden (37\%), yang berpendidikan SLTA mempunyai pengetahuan cukup terbanyak 7 responden (54\%), yang berpendidikan SD-SLTP mempunyai pengetahuan kurang terbanyak 6 responden (100\%). Menurut Notoadmodjo (2007) makin tinggi tingkat pendidikan seseorang makin mudah menerima informasi sehingga makin banyak pula pengetahuan yang diperkenalkan.

Dalam penelitian ini tidak ditemukan kesesuaian teori yang menyatakan bahwa tingkat pendidikan menentukan pengetahuan. $\mathrm{Hal}$ ini dapat terjadi karena keinginan dari dalam diri mereka untuk mencari informasi terbaru misalnya melalui media masa, internet, dan pengetahuan yang didapat dari pendidikan kesehatan demi kesehatan tubuh mereka masing-masing, sehingga mampu menentukan sikap untuk mengambil keputusan dalam melakukan pemeriksaan dengan rutin.

\section{Pengetahuan Ibu Tentang Deteksi Dini Kanker Leher Rahim Dengan Papsmeaar Berdasarkan Pekerjaan}

Berdasarkan tabel 4 dapat dilihat bahwa sebagian besar responden tidak bekerja yaitu sebanyak 15 responden (50\%). Menurut Nursalam (2003) seseorang yang mempunyai pekerjaan penting dan memerlukan aktifitas, maka akan merasa tidak ada waktu untuk memeriksakan kesehatan diri masing-masing, tapi tidak semua orang yang bekerja seperti demikian sebagian dari mereka dapat melakukan pemeriksaan dengan baik

Dalam penelitian ini berdasarkan tabel 4 ditemukan tidak sesuai dengan teori menurut Nursalam (2003) dari 30 responden yang bekerja swasta mempunyai pengetahuan baik terbanyak 7 responden (63\%), yang bekerja swasta mempunyai pengetahuan cukup terbanyak 8 responden (62\%), yang tidak bekerja mempunyai pengetahuan kurang terbanyak 1 responden (100\%), ibu yang bekerja swasta maupun PNS mempunyai pengetahuan baik karena kawatir akan kondisinya, meskipun mereka bekerja dan mempunyai waktu terbatas tapi mereka dapat meluangkan waktu untuk periksa papsmear dengan harapan jika terdapat gejala dapat diketahui sejak dini untuk kesehatan jangka panjang.

\section{SIMPULAN DAN SARAN}

\section{Simpulan}

Jadi dari hasil penelitian yang telah dilakukan didapatkan pembahasan seperti diatas sehingga dapat disimpulkan bahwa dari pengetahuan ibu untuk deteksi dini kanker leher rahim dengan papsmear berdasarkan usia, pendidikan, dan pekerjaan didapatkan dari 30 responden yang diamati hampir sebagian besar mempunyai pengetahuan baik dan pembahasan mengenai pengetahuan ibu untuk deteksi dini kanker leher rahim dengan papsmear di BPS Lilik Farida Surabaya dapat dibuktikan bahwa:

1. Pengetahuan ibu tentang deteksi dini kanker leher rahim dengan papsmear secara umum yang diperoleh dari 30 responden yang berpengetahuan baik 11 responden (37\%), yang berpengetahuan cukup 13 responden (43\%), yang berpengetahuan kurang 6 responden (20\%).

2. Pengetahuan ibu tentang deteksi dini kanker leher rahim dengan papsmear berdasarkan usia, 20-30 tahun yang mempunyai pengetahuan baik dalam pemeriksaan papsmear terbanyak 11 responden (40\%), yang mempunyai pengetahuan cukup 11 responden (40\%), dan pada usia > 40 tahun yang mempunyai pengetahuan kurang terbanyak 3 responden (12\%).

3. Berdasrkan pendidikan didapatkan hasil : pengetahuan baik 4 responden (37 \%) dengan pendidikan perguruan tinggi, pendidikan cukup 7 responden (54\%) dengan pendidikan SLTA dan sebanyak 6 responden (100\%) dengan pendidikan SD SLTP.

4. Berdasarkan pekerjaan didapatkan hasil : responden pekerja swasta memiliki pengetahuan cukup 10 responden (59\%), PNS terbanyak pengetahuan cukup 2 responden $(100 \%)$ dan tidak bekerja terbanyak 7 responden (67\%) pengetahuan cukup.

\section{Saran}

\section{Bagi Pelayanan Kesehatan}

Petugas dipelayanan kesehatan diharapkan memberikan pendidikan kesehatan, pentingnya pengetahuan tentang deteksi dini kanker leher rahim dengan papsmear kepada akseptor KB. 


\section{Bagi Akseptor KB}

Dalam upaya meningkatkan pengetahuan tentang deteksi dini kanker leher rahim dengan papsmear, perlu mengikuti penyuluhan-penyuluhan dari tenaga kesehatan, bisa juga melalui media masa.

\section{Peneliti Selanjutnya}

Perlu diadakan penelitian lebih lanjut tentang perilaku akseptor KB dalam melakukan pemeriksaan papsmear terhadap dirinya.

\section{DAFTAR ACUAN}

Arifin, Zainal. 2010. Metodelogi Penelitian. Surabaya:Lentera Cendikia

Ghofar, Abdul. 2009. Cara Mudah Mengenal \& Mengobati Kanker. Yogyakarta:Flamingo

Hidayat, A.Aziz Alimul.2007.Metode Penelitian Kebidanan Teknisi Analisa Data.Jakarta:Salemba Medika

Mangan, Yelia.2005.Cara Bijak Menaklukkan Kanker.Jakarta:Agro Media Pustaka

Manuaba, Ida Bagus Gde.1998.IImu Kebidanan, Penyakit Kandungan dan Keluarga Berencana untuk Pendidikan Bidan.Jakarta:EGC

Margatan,Arcole.1996. Waspada Kanker Payudara\&Rahim.Solo:CV.Aneka

Norwitz,Errol.2007.At a Glance Obstetri\&Ginekologi.Jakarta:Airlangga

Notoatmodjo,Soekidjo.2007.Metodologi Penelitian Kesehatan.Jakarta:Rineka Cipta

Nurcahyo,Jalu.2010.Awas Bahaya Kanker Rahim dan Kanker Payudara. Yogyakarta:Wahana Totalita.

Nursalam.2001.Manajemen Keperawatan.Jakarta:Salemba Medika

Prawirahardjo,Sarwono.2009. IlmuKebidanan.

\section{Jakarta:YBPSP}

Rahayu, Wahyu.2011.Mengenali,Mencegah Dan Mengobati 35 Jenis Kanker.: Victory Inti Cipta

Rasjidi, Imam.2009.Deteksi Dini \& Pencegahan Kanker Pada Wanita.Jakarta:CV Sagung Seto

Rasjidi,Imam.2010.EpidemiologiKanker. Jakarta:CV Sagung Seto

Rustam,Harahap.1984.Neoplasia Intraepitel pada Servik.Jakarta:Universitas Indonesia 